\title{
Two combined photosensitizers: a goal for more effective photodynamic therapy of cancer
}

\author{
P Acedo ${ }^{1}$, JC Stockert ${ }^{1}$, M Cañete ${ }^{1}$ and A Villanueva ${ }^{*, 1}$
}

Photodynamic therapy (PDT) is a clinically approved therapeutic modality for the treatment of diseases characterized by uncontrolled cell proliferation, mainly cancer. It involves the selective uptake of a photosensitizer (PS) by neoplastic tissue, which is able to produce reactive oxygen species upon irradiation with light, leading to tumor regression. Here a synergistic cell photoinactivation is reported based on the simultaneous administration of two PSs, zinc(II)-phthalocyanine (ZnPc) and the cationic porphyrin meso-tetrakis(4-N-methylpyridyl)porphine (TMPyP) in three cell lines (HeLa, HaCaT and MCF-7), using very low doses of PDT. We detected changes from predominant apoptosis (without cell detachment) to predominant necrosis, depending on the light dose used $\left(2.4\right.$ and $3.6 \mathrm{~J} / \mathrm{cm}^{2}$, respectively). Analysis of changes in cytoskeleton components (microtubules and F-actin), FAK protein, as well as time-lapse video microscopy evidenced that HeLa cells were induced to undergo apoptosis, without losing adhesion to the substrate. Moreover, $24 \mathrm{~h}$ after intravenous injection into tumor-bearing mice, $\mathrm{ZnPc}$ and TMPyP were preferentially accumulated in the tumor area. PDT with combined treatment produced significant retardation of tumor growth. We believe that this combined and highly efficient strategy (two PSs) may provide synergistic curative rates regarding conventional photodynamic treatments (with one PS alone).

Cell Death and Disease (2014) 5, e1122; doi:10.1038/cddis.2014.77; published online 13 March 2014

Subject Category: Cancer

Photodynamic therapy (PDT) is a multi-step and successful clinically approved oncologic therapeutic modality, which involves the selective uptake of a photosensitizer (PS) by neoplastic tissue followed by illumination with light of appropriate wavelength that is able to trigger photochemical reactions that lead to the generation of reactive oxygen species (ROS), mainly singlet oxygen $\left({ }^{1} \mathrm{O}_{2}\right)$, which result in tumor regression. PDT-based antitumor effects are multifactorial and include (i) direct killing of tumor cells, (ii) damage to the vasculature, and (iii) triggering of an antitumor immune response. ${ }^{1-3}$ PDT has been approved in several countries to treat a variety of cancers, such as skin, bladder, lung, esophagus, and cervix among others. ${ }^{2}$

PDT can be used in combination with a variety of currently used cancer therapies, including chemotherapy, ${ }^{4,5}$ radiation therapy, ${ }^{6}$ surgery, ${ }^{7}$ gene therapy, ${ }^{8}$ and immunotherapy, ${ }^{9}$ without compromising these therapeutic modalities. Moreover, the adverse effects of chemotherapy or radiotherapy are absent, and considering its unique ${ }^{1} \mathrm{O}_{2}$-dependent cytotoxic effects PDT can be safely combined without the risk of inducing cross-resistance.

Combined strategies have been introduced for cancer treatments, including PDT with tumor suppressors, ${ }^{10,11}$ inhibitors, ${ }^{12}$ and anti-angiogenic drugs. ${ }^{2}$ Another way to enhance PDT efficacy involves an increase in PS delivery and specificity through conjugation to tumor-targeting molecules. PS encapsulation into nanoparticles or combining PDT with agents that target signal transduction pathways, seems to increase efficacy and selectivity of PDT. ${ }^{13-15}$ However, there are few studies that have attempted to determine the effects of the combination of two PSs as a new strategy. ${ }^{2,16-18}$

In this study, we explored the photosensitized effects of PDT mediated by simultaneous administration of two PSs: zinc(II)-phthalocyanine $(\mathrm{ZnPc})$ and the cationic porphyrin meso-tetrakis(4- $N$-methylpyridyl)porphine (TMPyP), in different tumor cell lines as well as in tumor-bearing mice (preliminary results). Both PSs have high quantum yields of ${ }^{1} \mathrm{O}_{2}$ formation $\left(\Phi_{\Delta}=0.70\right.$ for $\mathrm{ZnPc}$ and $\Phi_{\Delta}=0.74$ for TMPyP $)^{19}$ and several research groups, including our own, have studied the photobiological properties of TMPyP 20,21 and $\mathrm{ZnPc}$ when they are administered individually. ${ }^{22-24}$

\section{Results}

Non-dark toxicity versus high phototoxicity. Both PSs and combined treatment were tested for $1 \mathrm{~h}$ without irradiation (dark toxicity) in all cell lines. Survival of cells by 3-(4,5-dimethylthiazol-2-yl)-2,5-diphenyltetrazolium bromide (MTT) colorimetric assay was $>90 \%$ in all the cases (see Supplementary Table 1). Likewise, irradiation alone

\footnotetext{
${ }^{1}$ Department of Biology, Faculty of Sciences, Autonomous University of Madrid, Madrid 28049, Spain

${ }^{*}$ Corresponding author: A Villanueva, Department of Biology, Faculty of Sciences, Autonomous University of Madrid, Madrid 28049, Spain. Tel: +34 91 4978236; Fax: +34 91 4978344; E-mail: angeles.villanueva@uam.es

Keywords: photodynamic therapy; cancer; combined strategy

Abbreviations: ALA, 5-aminolevulinic acid; $\mathrm{DiOC}_{6}(3), 3,3^{\prime}$-dihexyloxacarbocyanine iodide; FAK, focal adhesion kinase; FITC, fluorescein isothiocyanate; MTT, 3-(4,5-dimethylthiazol-2-yl)-2,5-diphenyltetrazolium bromide; $\Delta \Psi \mathrm{m}$, mitochondrial membrane potential; PDT, photodynamic therapy; PS, photosensitizer; PARP, poly (ADP-ribose) polymerase; PI, propidium iodide; ROS, reactive oxygen species; SEM, scanning electron microscopy; TMPyP, meso-tetrakis(4-N-methylpyridyl)porphine; TEM, transmission electron microscopy; TRITC, tetramethylrhodamine isothiocyanate; TUNEL, terminal deoxynucleotidyl transferase-mediated dUTP nick end labeling; ZnPc, zinc(II)-phthalocyanine

Received 28.10.13; revised 15.1.14; accepted 16.1.14; Edited by A Stephanou
} 
did not induce cytotoxicity (data not shown). Figure 1 shows changes in cell viability caused by different treatments. Photodynamic treatments with each PS alone did not significantly affect HeLa cell survival, at both 24 and $48 \mathrm{~h}$ after treatments. Only $\mathrm{ZnPc}$ within $24 \mathrm{~h}$ showed some degree of phototoxicity, but not more than $13 \pm 4 \%$, and at $48 \mathrm{~h}$ the surviving fraction increased to a value of $95 \pm 3 \%$. However, cells incubated with $\mathrm{ZnPc}+\mathrm{TMPyP}$ for $1 \mathrm{~h}$, followed by $4 \mathrm{~mW} / \mathrm{cm}^{2}$ irradiation (light dose $2.4 \mathrm{~J} / \mathrm{cm}^{2}, 10 \mathrm{~min}$ irradiation), showed a substantially higher phototoxicity (surviving fraction: $3 \pm 1 \%$ and $2 \pm 1 \%$ at 24 and $48 \mathrm{~h}$, respectively).

Results obtained using HaCaT cells $24 \mathrm{~h}$ after treatments (see Figure 1a) were similar to that described previously for HeLa cells. On the other hand, MCF-7 cells showed higher photosensitization at $24 \mathrm{~h}$. It is important to note that $48 \mathrm{~h}$ after photodynamic treatments with each PS alone, surviving fractions of both cell lines, HaCaT and MCF-7, increased until they attained similar values as described for control cells, but in the case of combined treatment we observed a decrease in cell viability, which confirmed a high inactivation efficiency of our combined strategy (see Figure 1b). Toxicity detected in HaCaT and MCF-7 cells after $24 \mathrm{~h}$ of incubation with $\mathrm{ZnPc}$ or TMPyP seems to involve a temporal metaphase arrest $3 \mathrm{~h}$ after both treatments, without affecting cell viability, as we visualized in samples of individual treatments by optical microscopy (see below), which would lead to a lower number of cells compared with controls, and therefore a smaller value in the MTT performed at $24 \mathrm{~h}$. Surviving fractions of all cell lines exposed to different light doses $\left(2.4\right.$ or $3.6 \mathrm{~J} / \mathrm{cm}^{2}$ ) without PS preincubation were similar to those of controls (data not shown). Balance between dark toxicity and cell photoinactivation suggested $5 \times 10^{-8} \mathrm{M} \mathrm{ZnPc}+10^{-6} \mathrm{M} \mathrm{TMPyP}$ and $2.4 \mathrm{~J} / \mathrm{cm}^{2}$ as the optimal concentration and light dose parameters for a highly effective in vitro photodynamic treatment.

Statistical evaluation (one-way ANOVA Tukey's test) showed that the PDT effect in combination-treated HeLa cells at 24 and $48 \mathrm{~h}$ differs significantly from control, $\mathrm{ZnPc}$ alone and TMPyP alone-treated cells $(P<0.0001$, in all cases). Cell viability differences between other groups were not significant at any time interval. In case of $\mathrm{HaCaT}$ cells, highly significant viability differences were observed between control, $\mathrm{ZnPc}$ or TMPyP versus combination-treated cells $(P<0.0001)$ at both post-treatment times. In ZnPc-treated HaCaT cells, weak significant differences were detected at $24 \mathrm{~h}$, but not at $48 \mathrm{~h}$, in comparison with control cells $(P<0.05)$. In MCF-7 cells, significant differences in cell viability were observed for the TMPyP group $(P<0.05)$ and the $\mathrm{ZnPc}$ group $(P<0.01)$ in comparison with controls at $24 \mathrm{~h}$, which were not significant at $48 \mathrm{~h}$. Highly significant differences were detected between the combination-treated group and all other groups $(P<0.0001)$ at both time intervals.

The combined effect of PDT (cells incubated with both PSs for $1 \mathrm{~h}$ and $2.4 \mathrm{~J} / \mathrm{cm}^{2}$ light dose) on cell viability can be defined as synergistic in all cell lines used, by applying the method of Valeriote and $\operatorname{Lin}^{25}$ (see Supplementary Table 2).

\section{Cells undergo massive apoptosis or necrosis depending on light dose}

Morphological criteria: Photodynamic treatments on HeLa cells, using 2.4 or $3.6 \mathrm{~J} / \mathrm{cm}^{2}$ light doses (10 or $15 \mathrm{~min}$ irradiation, respectively), resulted in different patterns of cell death morphology: apoptosis or necrosis, respectively, revealed by neutral red (NR) for general morphology and Hoechst-33258 (H-33258) staining for DNA visualization (Figure 2A). Well-known morphological criteria ${ }^{26}$ were used for identification of apoptotic and necrotic cells.

HeLa cells treated with one PS alone or only irradiated presented similar morphology to control cells (data not shown). However, after photodynamic treatment with $\mathrm{ZnPc}+$ TMPyP, HeLa cells showed significant morphological changes, depending on the time elapsed after the end of treatment $(3,6$, and $24 \mathrm{~h})$ and on light dose. Figure $2 \mathrm{Ab}-\mathrm{d}$ shows the effect of incubation with both PSs for $1 \mathrm{~h}$, followed by 2.4 or $3.6 \mathrm{~J} / \mathrm{cm}^{2}$ light dose. As shown in Figure 2Ab, a large number of HeLa cells have undergone apoptosis $3 \mathrm{~h}$ after photodynamic treatment, as deduced from cell shrinkage, chromatin condensation, and nuclear fragmentation, which are typical apoptotic features. At $6 \mathrm{~h}$ (Figure 2Ac) and $24 \mathrm{~h}$ (data not shown), most cells have undergone apoptosis and only few cells remain alive. Likewise, typical evolution of necrotic morphological alterations was observed when the light dose was increased to $3.6 \mathrm{~J} / \mathrm{cm}^{2}$. Changes began immediately after irradiation and $6 \mathrm{~h}$ later the plasma membrane formed a giant bubble (Figure 2Ad). Also, uniform
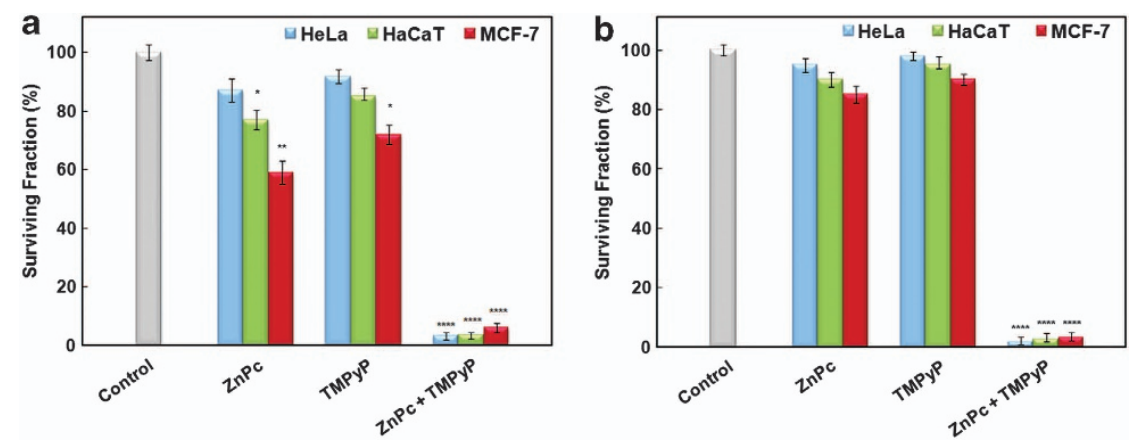

Figure 1 Surviving fractions of HeLa, HaCaT, and MCF-7 cells incubated with ZnPc $5 \times 10^{-8} \mathrm{M}$, TMPyP $10^{-6} \mathrm{M}$, or ZnPc $5 \times 10^{-8} \mathrm{M}+\mathrm{TMPyP} 10^{-6} \mathrm{M}$ for $1 \mathrm{~h}$, followed by red irradiation $\left(2.4 \mathrm{~J} / \mathrm{cm}^{2}\right)$ at $24(\mathbf{a})$ and $48 \mathrm{~h}(\mathbf{b})$. Combined treatment produces highly significant effects on the survival of the three cell lines used. Data correspond to mean \pm S.D. values from at least six different experiments. Statistically significant differences are labeled as ${ }^{*} P<0.05,{ }^{* *} P<0.01$, and ${ }^{* * * *} P<0.0001$, for comparisons between groups using one-way ANOVA with Tukey's multiple comparison post-hoc test. In all cell lines at 24 and $48 \mathrm{~h}$ : combination-treated cells versus all other groups $\left(^{* * * *)}\right.$. In HaCaT cells only at $24 \mathrm{~h}$ : ZnPc versus control $\left({ }^{*}\right)$. In MCF-7 cells only at $24 \mathrm{~h}$ : TMPyP versus control $\left(^{*}\right)$ and $\mathrm{ZnPc}$ versus control (**) 
A
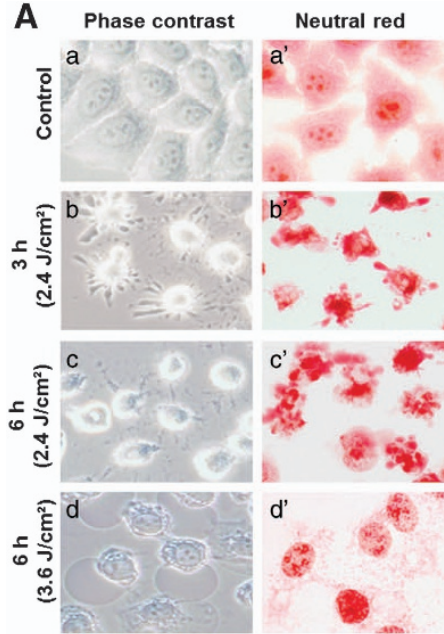
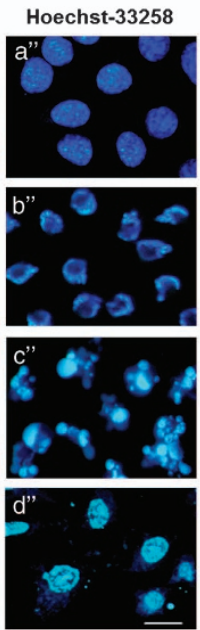



Figure 2 (A) Morphology of HeLa cells in phase contrast or DIC and after NR or H-33258 staining. (a-a $\mathrm{a}^{\prime \prime}$ ) Control cells. (b-c $\mathrm{c}^{\prime \prime}$ ) Cells incubated for $1 \mathrm{~h}$ with both PSs followed by red light irradiation $\left(2.4 \mathrm{~J} / \mathrm{cm}^{2}\right.$ ) and observed 3 and $6 \mathrm{~h}$ later, respectively. Note the increasing amount of cells with clear apoptotic morphology (cell shrinkage and chromatin fragmentation). ( $\mathrm{d}-\mathrm{d}^{\prime \prime}$ ) Morphological changes of cells incubated for $1 \mathrm{~h}$ with both PSs and subjected to red light irradiation $\left(3.6 \mathrm{~J} / \mathrm{cm}^{2}\right), 6 \mathrm{~h}$ after treatment. Note the homogeneous nuclear condensation and giant bubbles characteristic of necrosis. Scale bar $=10 \mu \mathrm{m}$. (B) Percentage of apoptotic or necrotic HeLa cells $24 \mathrm{~h}$ after combinedphotodynamic treatment using two different light doses, 2.4 or $3.6 \mathrm{~J} / \mathrm{cm}^{2}$, respectively. Values are mean \pm S.D. of three independent determinations

chromatin condensation leading to pyknotic nuclei was detected. Twenty-four hours after treatment, giant bubbles were broken and cytoplasm remnants were found still attached to the culture substrate (data not shown).

In order to discard possible interactions between TMPyP and DPPC liposomes, we performed PDT experiments $(2.4 \mathrm{~J} /$ $\mathrm{cm}^{2}$ ) after simultaneous incubation of HeLa cells for $1 \mathrm{~h}$ with empty control liposomes (DPPC without ZnPc) or TMPyP + empty DPPC. As can be seen in Supplementary Figure 1A, $24 \mathrm{~h}$ after phototreatments, HeLa cells preincubated with TMPyP + empty DPPC showed similar morphology to TMPyP-treated cells, and we confirmed that this toxicity was not due to DPPC mixture alone (no $\mathrm{ZnPc}$ ). Thus, it seems unlikely any interaction of cationic porphyrin with DPPC liposomes. Furthermore, we analyzed whether the mechanism of entry could be altered when both PSs were administered together. We performed incubations of HeLa cells for $1 \mathrm{~h}$ with combined PSs at $4{ }^{\circ} \mathrm{C}$, commonly used for endocytosis inhibition. Twenty-four hours after PDT (light dose $2.4 \mathrm{~J} / \mathrm{cm}^{2}$ ), cell morphology was not altered when incubation was performed at low temperature, because of the fact that cells did not have enough ATP levels required for endocytic incorporation of $\mathrm{ZnPc}$ inside HeLa cells (Supplementary Figure 1B).

Moreover, we have carried out a morphological analysis of phototreatments (using $2.4 \mathrm{~J} / \mathrm{cm}^{2}$ light dose) with each PS alone or administered in combination in both HaCaT and MCF-7 cell lines (see Supplementary Figure 2). Cells only irradiated presented similar morphology to control cells (data not shown). As can be seen in Supplementary Figure 2, while $3 \mathrm{~h}$ after ZnPc-PDT or TMPyP-PDT treatment (in case of MCF-7 cells, or only after ZnPc-PDT in HaCaT cells) a slight increase in number of metaphase cells could be detected (with chromosomes properly aligned in the equatorial plate), $48 \mathrm{~h}$ after individual photodynamic treatments there were no signs of toxicity (data not shown). On the contrary, combined
PDT induced deep morphological changes characteristic of an apoptotic death, depending on time elapsed after the end of treatment in both cell lines. Therefore, these results confirm that synergistic effect, with most cell death induced by apoptosis, is not exclusive of the HeLa cell line.

Electron microscopy studies: Micrographs taken by scanning electron microscopy (SEM) confirmed previous results. Interphase control cell morphology (Figure 3Aa) was flattened as well as polygonal, and cell surface showed numerous connections between plasma membrane of neighboring cells. However, $3 \mathrm{~h}$ after apoptotic treatment (Figure $3 A b$ ), almost all cells were shrunken, had numerous vesicles and showed prolongations attached to the substrate. Six hours later (Figure 3Ac), cells showed typical apoptotic morphology with deformations of membrane as 'blebs' and loss of intercellular connections. At $24 \mathrm{~h}$, only apoptotic cell debris were observed (data not shown). After necrotic treatment (when light dose was increased to $3.6 \mathrm{~J} / \mathrm{cm}^{2}$ ), loss of plasma membrane integrity was clearly visualized by SEM as a common morphological alteration. HeLa cells started the process with an immediate and massive production of small surface evaginations (bubbles), but without membrane disruption. A few minutes later, these surface deformations converged into a big, single bubble. Particularly, cells observed by SEM after $6 \mathrm{~h}$ of this treatment (Figure $3 \mathrm{Ad}$ ) exhibited plasma membrane rupture after detachment of the giant bubble, with gradual liberation of cytoplasmic content.

Control cells' images taken by transmission electron microscopy (TEM) showed a large nucleus with finely dispersed chromatin, where small nucleoli were sometimes evident (Figure 3Ba). In the cytoplasm we observed mitochondria, narrow profiles of endoplasmic reticulum, and Golgi apparatus with flattered overlapping cisternae. At 3 and $6 \mathrm{~h}$ after irradiation, combination-treated cells appeared with typical apoptotic morphology (Figures 3Bb and Bc). Three 
hours after necrotic treatment, membranous cell components were swollen and optically empty, although no evident nuclear damage could be detected. At $6 \mathrm{~h}$, cells showed an extensive number of vesicles, with no clearly distinguishable organelles and strongly compacted chromatin masses (Figure 3Bd).
Combined PDT triggers apoptosis via mitochondrialrelated pathway. After combined PDT, HeLa cells showed a relevant depolarization of mitochondrial membrane potential $(\Delta \Psi \mathrm{m})$ (Figure 4A). Especially $18 \mathrm{~h}$ after treatment, cells' hypofluorescence increased to $79.3 \%$ compared with controls (1.2\%). Annexin-V assay results obtained for Hela

\section{A}
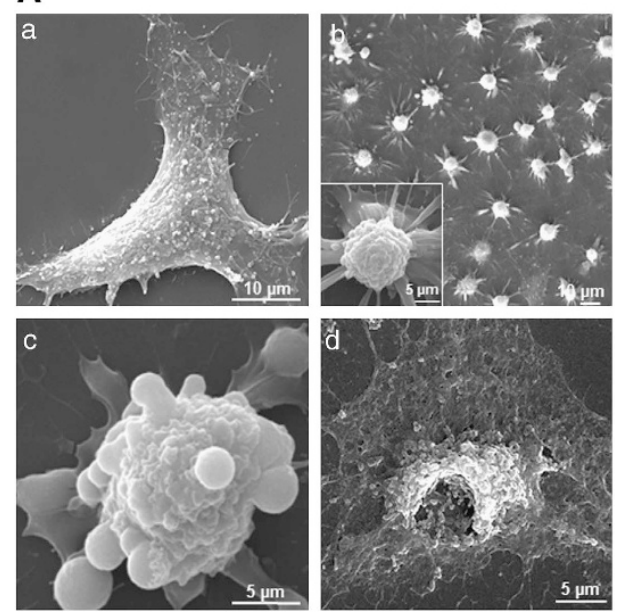

B
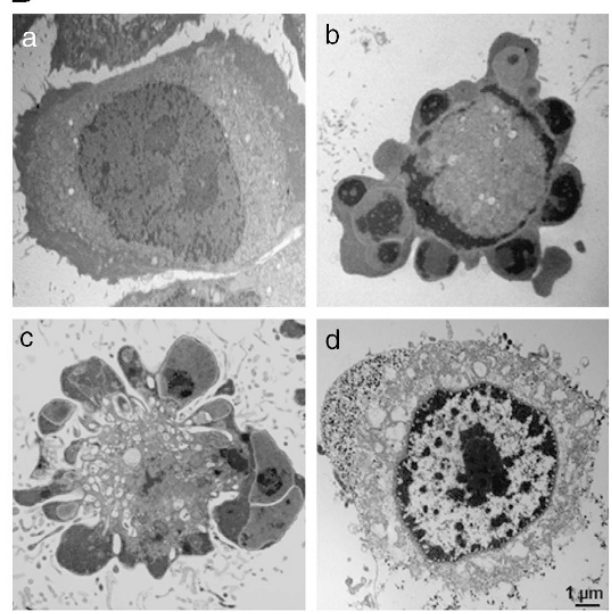

Figure 3 (A) Morphological changes of HeLa cells incubated $1 \mathrm{~h}$ with both PSs and subjected to red light irradiation, visualized by scanning electron microscopy (SEM). (a) Interphase control cell. (b) Apoptotic cells observed for $3 \mathrm{~h}$ upon PDT $\left(2.4 \mathrm{~J} / \mathrm{cm}^{2}\right)$. (c) Cells in apoptosis $6 \mathrm{~h}$ after treatment $\left(2.4 \mathrm{~J} / \mathrm{cm}^{2}\right)$. (d) Rest of the necrotic cells $6 \mathrm{~h}$ after PDT $\left(3.6 \mathrm{~J} / \mathrm{cm}^{2}\right)$. (B) Micrographs taken by transmission electron microscopy (TEM). (a) Untreated (control) cells. (b) Apoptotic cells $3 \mathrm{~h}$ after combined PDT $\left(2.4 \mathrm{~J} / \mathrm{cm}^{2}\right.$ ). (c) Typical apoptotic cells $6 \mathrm{~h}$ after PDT $\left(2.4 \mathrm{~J} / \mathrm{cm}^{2}\right)$. (d) Necrotic cells $6 \mathrm{~h}$ after PDT $\left(3.6 \mathrm{~J} / \mathrm{cm}^{2}\right)$
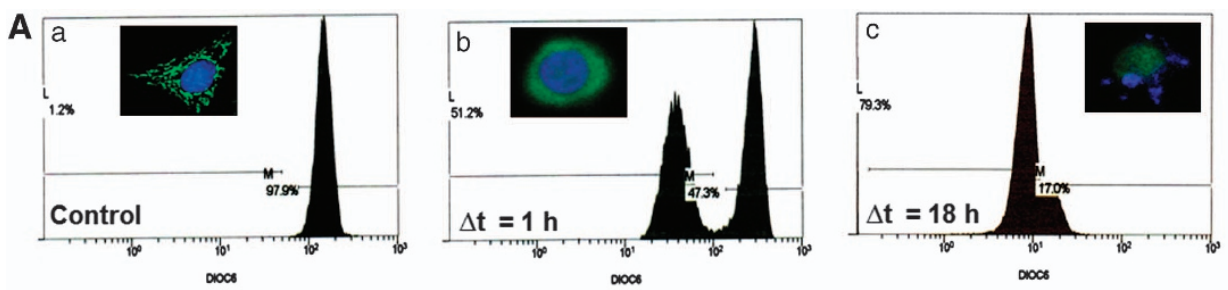

B

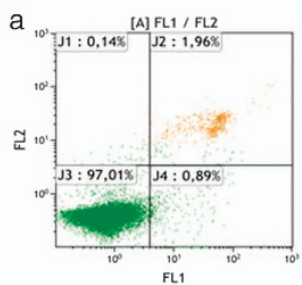

Control

C
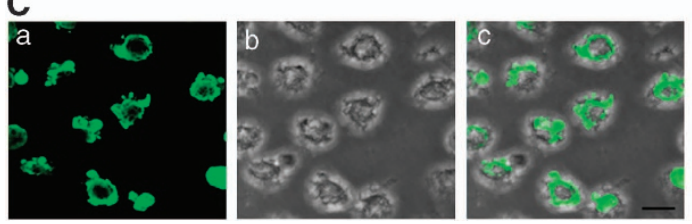

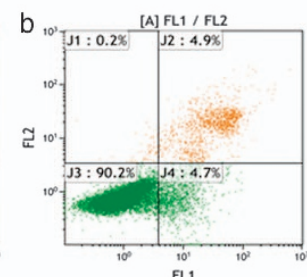

$\Delta t=1 \mathrm{~h}\left(2.4 \mathrm{~J} / \mathrm{cm}^{2}\right)$

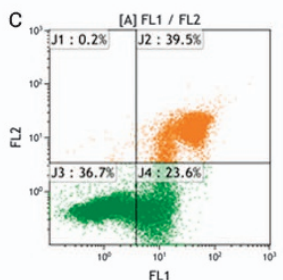

$\Delta t=3 \mathrm{~h}\left(2.4 \mathrm{~J} / \mathrm{cm}^{2}\right)$

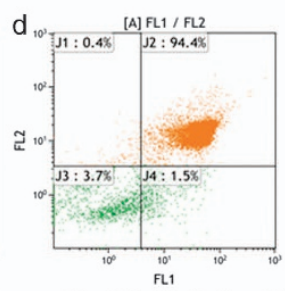

$\Delta t=3 \mathrm{~h}\left(3.6 \mathrm{~J} / \mathrm{cm}^{2}\right)$

\section{D}

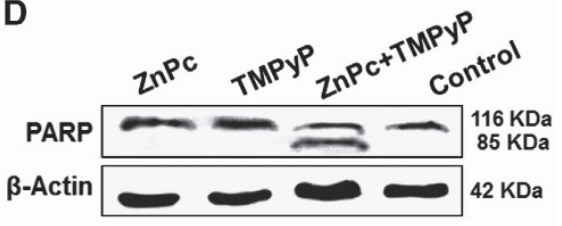

Figure 4 (A) Analysis of mitochondrial membrane potential $\left(\Delta \psi_{\mathrm{m}}\right)$ by flow cytometry revealed by $\mathrm{DiOC}_{6}(3)$ fluorescence and representative images of cell sample in fluorescence microscopy. (a) Control cells. (b, c) HeLa cells after combined PDT for 1 and $18 \mathrm{~h}$, respectively. (B) Representative flow cytometry histograms of annexin-V-FITC in combination with PI staining detection. (a) Control cells. (b, c) Treated cells $\left(2.4 \mathrm{~J} / \mathrm{cm}^{2}\right) 1$ and $3 \mathrm{~h}$ upon combined treatment, respectively. (d) Treated cells at $3 \mathrm{~h}\left(3.6 \mathrm{~J} / \mathrm{cm}^{2}\right)$. (C) Apoptotic cells after $6 \mathrm{~h}$ combined treatment were assessed by TUNEL assay. (a) Bright green fluorescent nuclear spots represent TUNEL-positive cells. (b) Phase contrast or DIC. (c) Merged image. Scale bar $=10 \mu \mathrm{m}$. (D) Fragmentation of PARP revealed by western blotting. Only cells treated with both PSs and irradiated $\left(2.4 \mathrm{~J} / \mathrm{cm}^{2}\right)$ showed cleavage of PARP into two fragments 
cells are shown in Figure 4B. Combination-treated cells $\left(2.4 \mathrm{~J} / \mathrm{cm}^{2}\right)$ showed first annexin-V labeling of plasma membranes between 1 and $2 \mathrm{~h}$. Partial propidium iodide (PI) nuclear staining was detectable at later time points (2-3h). Annexin-V maximum fluorescence was detectable at $3 \mathrm{~h}$ with $24 \%$ early apoptotic cells (annexin- $\mathrm{V}^{+}, \mathrm{Pl}^{-}$) and $40 \%$ late apoptotic cells (annexin- $\mathrm{V}^{+}, \mathrm{Pl}^{+}$). At $3 \mathrm{~h}$ percentage of cell viability was only $36 \%$. On the other hand, at $3 \mathrm{~h}$ when light dose was increased to $3.6 \mathrm{~J} / \mathrm{cm}^{2}$, percentage of necrotic cells was $94 \%$ and cell viability was only $4 \%$. A positive TUNEL staining was observed at $6 \mathrm{~h}$ in almost all treated cells processed (Figure $4 \mathrm{C}$ ), indicating that these cells undergo DNA fragmentation between 3 and $6 \mathrm{~h}$ after treatment. Figure 4D shows that cleavage of poly (ADPribose) polymerase (PARP) was visible only when cells were treated with combined PDT. All these results demonstrate that combined treatment induces cell death with high efficiency, and the mechanism changes from predominantly apoptosis $(>91 \%)$ to predominantly necrosis (>89\%), depending on the light dose used.

Using indirect immunofluorescence, relocalization of proapoptotic Bax protein within mitochondria could be observed. One hour after combined treatment almost $80 \%$ of treated cells displayed the same subcellular Bax localization as control cells, but in contrast, 3 and $6 \mathrm{~h}$ after photodynamic treatment, cells displayed intense green fluorescence in mitochondria (Figure 5Ab-d). It is important to remark that $3 \mathrm{~h}$ after light exposure it was still possible to find cells with diffuse Bax signal $(\sim 25 \%)$, clearly distinguishable from apoptotic ones showing mitochondrial Bax localization. An increase in percentage of apoptotic cells was consistent with time evolution, reaching a maximum value after $6 \mathrm{~h}$ treatment. Interestingly, some cells showed Bax relocalization but non-fragmented nuclei ( $3 \mathrm{~h}$ after PDT, Figure 5Ac), which indicates that apoptotic Bax relocalization into mitochondria precedes nuclear fragmentation. Immunofluorescence techniques showed that cytochrome $c$ was confined to mitochondria in control cells and at early times following apoptotic PDT. After $1 \mathrm{~h}$ PDT, a significant fraction of cells showed swollen mitochondria with spherical shape around the nucleus, but cytochrome $c$ had not yet been released (Figure $5 \mathrm{Bb}$ ). However, $6 \mathrm{~h}$ after irradiation, a majority of cells displayed diffuse fluorescence and showed fragmented chromatin (Figure 5Bd).

Taking all these results together we demonstrated that treatment with $\mathrm{ZnPc}+\mathrm{TMPyP}$ for $1 \mathrm{~h}$ followed by irradiation $\left(2.4 \mathrm{~J} / \mathrm{cm}^{2}\right)$ induced massive apoptotic cell death (>91\%), whereas a high light dose $\left(3.6 \mathrm{~J} / \mathrm{cm}^{2}\right)$ produced a lethal effect associated with necrosis (>89\%).

Cytoskeleton disorganization during apoptosis without cell detachment. To get insight into the mechanisms of cell inactivation, we investigated the effects of combined PDT on actin microfilaments and focal adhesion kinase (FAK) distribution. In control cells FAK was located in focal adhesion points, whereas microfilaments were perfectly organized as stress and cortical fibers (Figure 6a- $d^{\prime}$ ). After $1 \mathrm{~h}$ post irradiation, cells were rounded and showed a clear retraction with maintenance of long extensions, like large filopodia, containing F-actin. FAK was much less expressed relative to control cells, but there were still small bright green spots, responsible for maintaining cell adhesion. At $3 \mathrm{~h}$, but mainly $6 \mathrm{~h}$ after combined treatment, a clear reduction in FAK expression and F-actin inside cells with apoptotic chromatin was detected (Figure $6 \mathrm{~m}-\mathrm{p}^{\prime}$ ). At $24 \mathrm{~h}$ both proteins showed almost missing expression (Figure $6 \mathrm{q}-\mathrm{t}^{\prime}$ ).

Moreover, using time-lapse video microscopy we observed that synergistic treatment $\left(2.4 \mathrm{~J} / \mathrm{cm}^{2}\right)$ induces a progressive

A
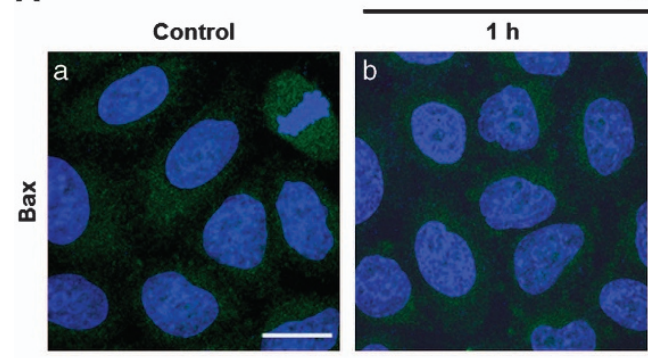

Time after PDT (2.4
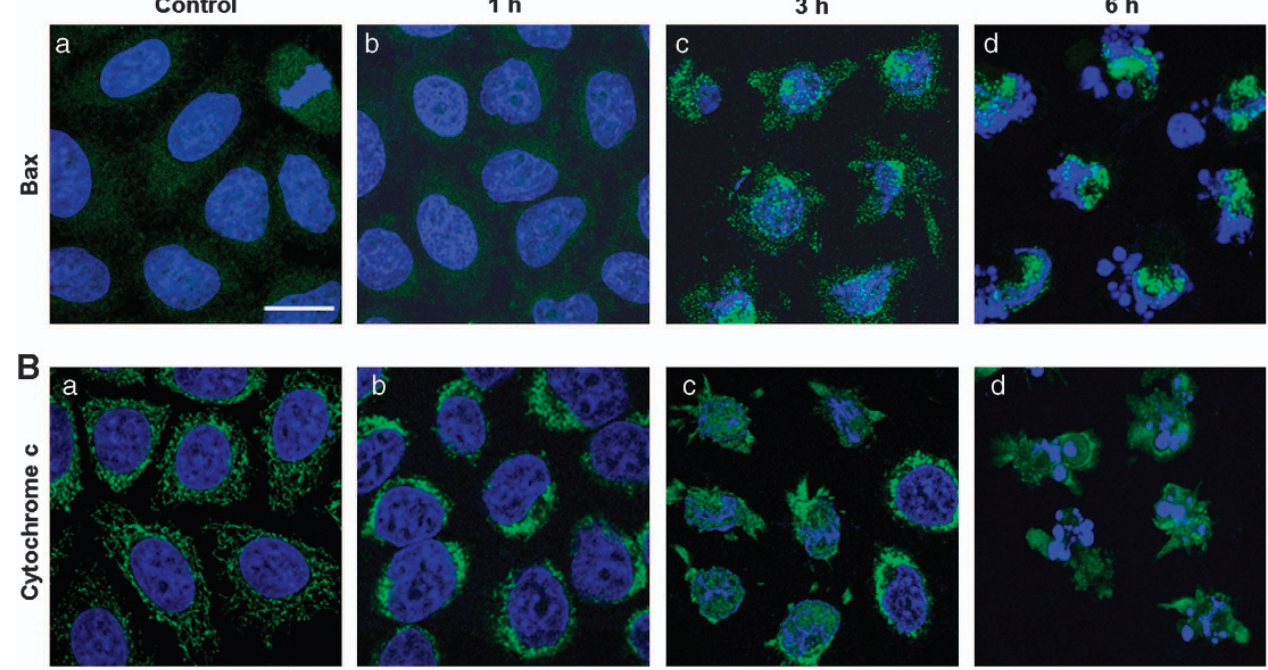

Figure 5 Apoptosis induction after $1 \mathrm{~h}$ treatment with $5 \times 10^{-8} \mathrm{M} \mathrm{ZnPc}+10^{-6} \mathrm{M}$ TMPyP followed by $2.4 \mathrm{~J} / \mathrm{cm}^{2}$ irradiation. (A) HeLa cells visualized by Bax immunofluorescence (green) and $\mathrm{H}-33258$ counterstaining of nuclei (blue). (a Control cells with diffuse Bax signal. (b-d) Cells 1, 3, and $6 \mathrm{~h}$ after photodynamic treatment, respectively, showing mitochondrial Bax signal in cells with condensed and fragmented chromatin 3 and $6 \mathrm{~h}$ after photodynamic treatment. (B) Effect of combined PDT on subcellular distribution of cytochrome $c$ detected by indirect immunofluorescence staining (green) and DNA counterstaining with H-33258 (blue). (a) Untreated cells. (b-d) HeLa cells 1,3 , and $6 \mathrm{~h}$ after treatment. Cytochrome $c$ was released to the cytosol in cells showing condensed and fragmented chromatin $6 \mathrm{~h}$ after irradiation. Scale $\operatorname{bar}=10 \mu \mathrm{m}$ 

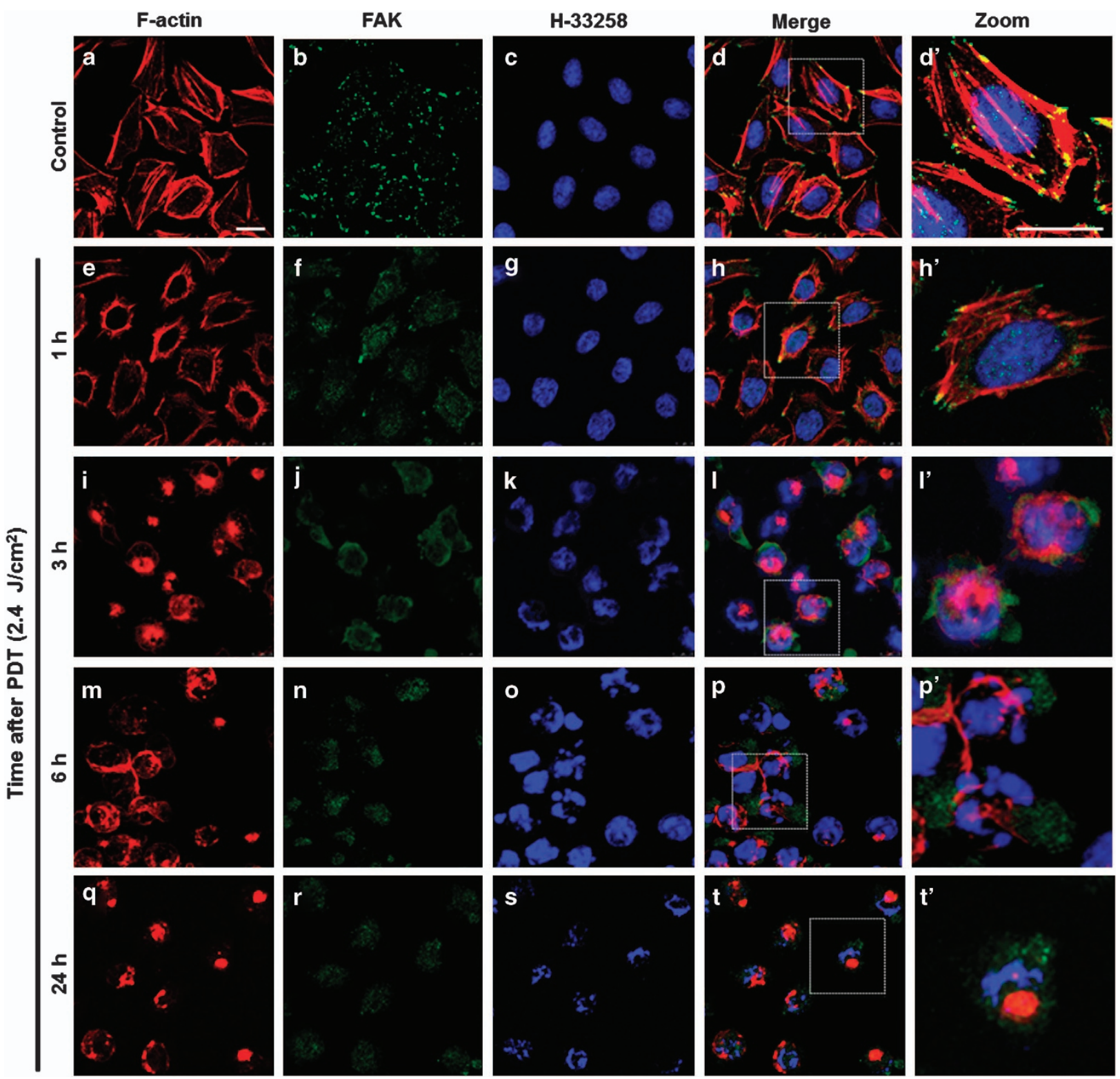

Figure 6 Phalloidin-TRITC visualization of F-actin (red), immunofluorescence of FAK (green), H-33258 staining of DNA (blue), merged and higher-magnification images in HeLa cells. (a-d') Control cells. (e-t') Cells $1,3,6$, and $24 \mathrm{~h}$ after combined treatment, respectively. Scale bar $=10 \mu \mathrm{m}$

entry of cells in apoptosis and that cells passed the complete apoptotic process, without losing their adhesion to substrate (Figure 7A and Supplementary Movie 1). On the other hand, we corroborated by this technique that necrosis was the main cell death mechanism induced when light dose was increased to $3.6 \mathrm{~J} / \mathrm{cm}^{2}$ (Supplementary Movie 2). We also analyzed cell migration by scratch wound assay for a total period of $48 \mathrm{~h}$, in order to determine if quantifiable cell migration occurred after synergistic-PDT treatment (Figure 7B). Our results showed that the minimal fraction of HeLa cells not committed to cell death did not display any capacity of closing wounds following PDT-induced damage.

Finally, we studied the percentage of attached cells immediately and $24 \mathrm{~h}$ after different treatments. Treated cells showed very effective attachment, which revealed that combined treatments did not significantly affect cell adhesion (Supplementary Figure 3).

Tumor localization properties of both PSs and in vivo effectiveness of the combined PDT strategy. We have studied the time-dependent distribution of intravenous (i.v.) injected $\mathrm{ZnPc}$ and TMPyP in C57BL/6 mice bearing a subcutaneously transplanted amelanotic melanoma. Images showed a very intense and selective accumulation of PSs in tumor regions (Figure 8A). Measured hours were selected as the best times for different experimental conditions (maximum fluorescence was detectable at $24 \mathrm{~h}$ ). Control mice injected with PBS only showed low background fluorescence at any time interval. 
A
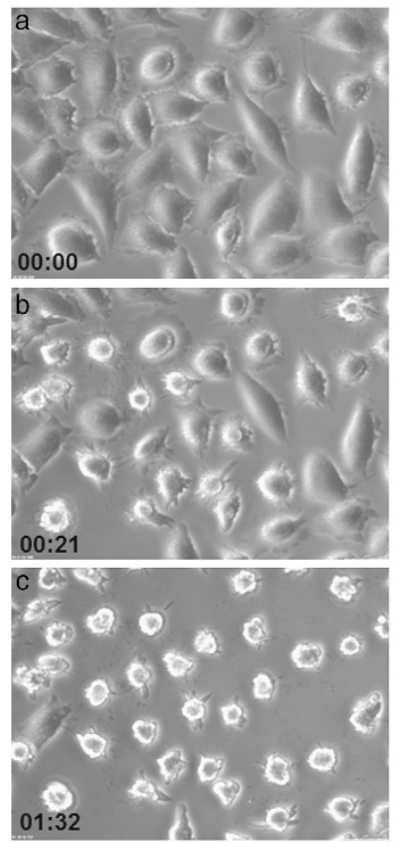

B

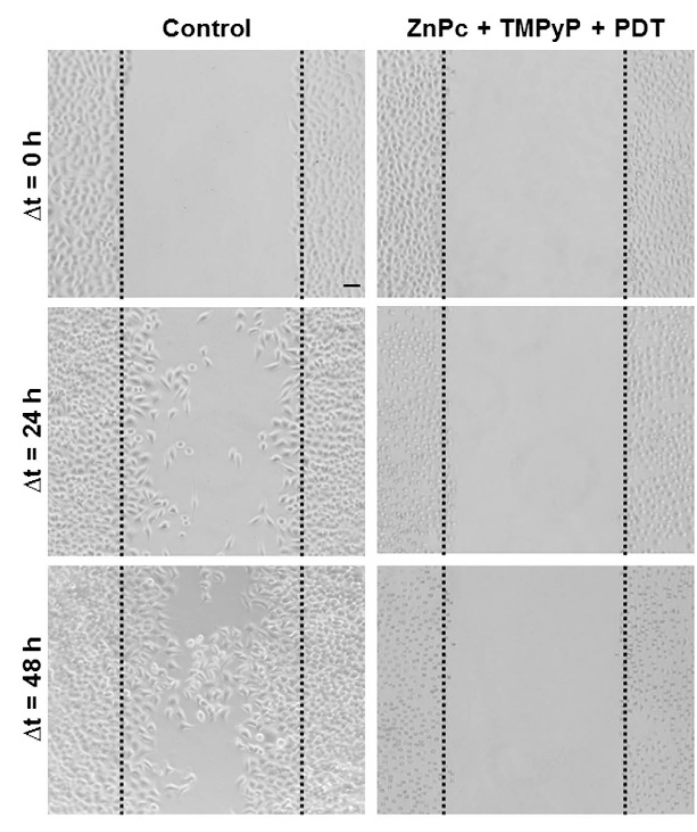

Figure 7 (A) (a-c) Selected images of time-lapse videos from the same field of a HeLa cell culture showing initiation and progression of apoptosis after synergistic PDT treatment. Numbers at the bottom-left of each frame denote the time elapsed from the moment of irradiation ( 0,30 and 90 min). (B) Analysis of cell migration by scratch wound assay. Only a negligible fraction of HeLa cells shows the capacity of closing wounds following PDT-induced damage. Scale bar $=50 \mu \mathrm{m}$

a

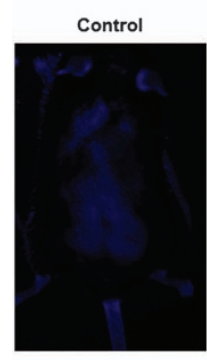

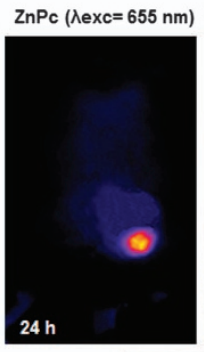

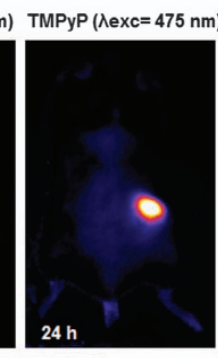

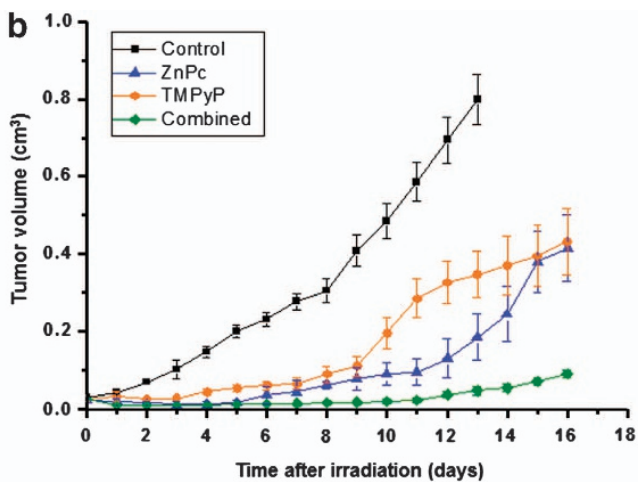

Figure 8 (a) Fluorescence images of in vivo accumulation of each PS were taken $24 \mathrm{~h}$ after intravenous injection and processed by ImageJ software (lookup table: fire). Exciting wavelengths are indicated. Color code for fluorescence intensity: white $>$ yellow $>$ orange $>$ red $>$ purple $>$ blue $>$ black. Control mouse was injected only with PBS. (b) Plots of mean tumor volumes in C57BL/6 mice bearing a subcutaneously transplanted amelanotic melanoma, after PDT treatments $(600-700 \mathrm{~nm}$, fluence rate of $175 \mathrm{~mW} / \mathrm{cm}^{2}$ for a total fluence of $300 \mathrm{~J} / \mathrm{cm}^{2}$ ) at $24 \mathrm{~h}$ after i.v. injection of $0.5 \mathrm{mg} / \mathrm{kg} \mathrm{ZnPc}$ and $/$ or $4.1 \mathrm{mg} / \mathrm{kg} \mathrm{TMPyP}$. Control group represents an absolute control (no light and no drug). Points are means of 6-8 tumors and bars are S.D.

Next, we decided to evaluate in this murine model the antitumor activity of the combined treatment. Figure 8B shows a clearly detectable time-dependent delay in the rate of tumor growth for individual or combined PDT for 16 days after phototreatments. Subsequent tumor growth was appreciably faster in mice treated only with ZnPc-PDT or TMPyP-PDT, and tumor responses became overlapped between both PDT treatments after 13 days. In contrast, combined therapy of both PSs was clearly the most effective treatment, leading to a delay in tumor regrowth, and a significant survival advantage potentiated the antitumor effects of PDT. This group resulted in a total regression of the principal tumor and stayed in remission for almost the whole course of observation. No significant differences in survival or tumor volume progress were observed between the different control groups: dark control (injection of each PS alone or in combination, but with no red light), light control (no drug), and absolute control (no light and no drug), so we only plotted the absolute control for the sake of clarity.

\section{Discussion}

In a previous study, we have proposed a new strategy to improve the efficiency of PDT by combined application of two PSs, ZnPc and TMPyP. ${ }^{17}$ The results reported here were obtained after analyzing in depth the synergistic effect of $\mathrm{ZnPc}+\mathrm{TMPyP}$ to kill cancer cells in culture. There are few in vitro PDT studies on the action mechanisms induced after 
simultaneous administration of two PSs, leading to a significantly higher phototoxicity of neoplastic cells. ${ }^{16,18}$

MTT cytotoxicity assays in MCF-7 and HaCaT human cell lines were similar to those obtained previously in HeLa cells (see Figure 1). An efficient synergistic effect (cell inactivation $>94 \%$ ) was achieved by $1 \mathrm{~h}$ of incubation with $\mathrm{ZnPc}$ $\left(5 \times 10^{-8} \mathrm{M}\right)$ and TMPyP $\left(10^{-6} \mathrm{M}\right)$ followed by red light irradiation (dose $2.4 \mathrm{~J} / \mathrm{cm}^{2}$ ) on the three lines analyzed.

Moreover, it should be emphasized that our in vitro conditions for cell inactivation are significantly lower than those described for other PSs, including those already accepted for clinical trials. ${ }^{27,28}$ When comparing photosensitization efficiencies between different PSs, the variability of treatment parameters is a question that has been highlighted in numerous publications. ${ }^{28,29}$ In this sense, our research group has a long experience in the comparative analysis of PS effectiveness (either commercialized or newly synthesized). None of them have required experimental conditions so low to inactivate tumor cells in culture. For instance, $\mathrm{ZnPc}$ required a concentration 100 times higher $\left(5 \times 10^{-6} \mathrm{M}\right)$ than the one used in the combined treatment with cationic porphyrin, to induce a lethal photodynamic effect in HeLa cells. ${ }^{30}$

It is also important to emphasize the complete absence of cytotoxicity exerted by combined administration of $\mathrm{ZnPc}$ and TMPyP, in the absence of light irradiation in all cell lines tested. Null dark toxicity is a property that must possess an ideal PS to avoid unwanted side effects when administered to patients. ${ }^{3}$ Based on positive results obtained in cytotoxicity assays, further studies were focused on HeLa cells in order to characterize cell death mechanisms.

Morphological analysis under optical and electron microscopy constitutes a very important tool to identify the specific type of cell death unambiguously. ${ }^{26,31}$ Some studies indicate that features considered characteristic of apoptosis can also take place during autophagy, especially when they lack essential apoptotic modulators like Bax and Bak or caspases. $^{32}$ Multiple microscopy techniques showed that phototreatment with $\mathrm{ZnPc}+\mathrm{TMPyP}$ induces mainly apoptotic cell death ( $>91 \%$ ) or necrosis ( $>89 \%$ ) depending on the light dose received $\left(2.4\right.$ versus $\left.3.6 \mathrm{~J} / \mathrm{cm}^{2}\right)$. Numerous investigations have shown that a shift in the mode of cell death, from apoptosis to necrosis, is dependent on a variety of parameters, including the nature of PS, cell genotype and PDT dose (PS concentration, light fluence or both). ${ }^{2,33,34}$ Each of these types of cell death depends on the intracellular energy levels, and is characterized by a set of morphological and biochemical features, allowing to identify the type of death mechanism involved. ${ }^{26,31,35}$ Apoptotic treatment induced deep morphological alterations, which occurred at variable time intervals. Cells do not respond at the same time to apoptotic conditions; thus it is necessary to determine the time interval during which the greater amount of cells undergoes some of the stages that define this type of cell death. ${ }^{26}$ However, it is noteworthy that most effective PSs described so far can also induce very effective apoptotic responses, but they require more drastic experimental conditions than those used in the present study. ${ }^{27,28}$

Studies carried out over the last decade have confirmed that PDT can evoke apoptosis, autophagy, mitotic catastrophe, and necrotic cell death pathways. ${ }^{2,33,36}$ We have performed several assays to elucidate the molecular mechanism behind apoptosis as the primary mode of HeLa cell death induced by combined PSs and light $\left(2.4 \mathrm{~J} / \mathrm{cm}^{2}\right)$. Results obtained by flow cytometry showed a relatively rapid and progressive loss of $\Delta \Psi_{\mathrm{m}}$ after phototreatment. Massive apoptotic response induced by combined treatment was confirmed by annexin-V/PI tests, TUNEL assay, and PARP fragmentation. The loss of $\Delta \Psi_{\mathrm{m}}$ in $50 \%$ of cells $1 \mathrm{~h}$ after synergistic treatment $\left(2.4 \mathrm{~J} / \mathrm{cm}^{2}\right)$ clearly indicates that the mitochondrial apoptotic pathway was triggered. ${ }^{32,37}$ Results of subcellular location of pro-apoptotic protein Bax showed that $3 \mathrm{~h}$ (but mostly $6 \mathrm{~h}$ ) after irradiation the strong green fluorescent signal of Bax appeared to be located in the mitochondria. Likewise, location of cytochrome $c$ showed complementary results to those of Bax. Although $1 \mathrm{~h}$ after PDT treatment, cytochrome $c$ is still located in the mitochondria, 3 and $6 \mathrm{~h}$ later diffuse green fluorescence was found in cytosol. At this time, cells showed characteristic apoptotic chromatin condensation and fragmentation.

In summary, synergistic treatment induces a progressive entry of cells in apoptosis. Six hours after irradiation, most of the cells were inactivated, triggered by the mitochondrial pathway. Considering that subcellular localization of PS has a fundamental role in the organelle where primary injury is due to ${ }^{1} \mathrm{O}_{2}$ generation (mainly responsible for cytotoxic effects), which has a lifetime of $1 \times 10^{-7} \mathrm{~s}$ in cells and a diffused distance of approximately $30 \mathrm{~nm},{ }^{38}$ it becomes clear that location of both PSs is an essential factor in the synergistic effect. In our previous research we found that TMPyP and $\mathrm{ZnPc}$ were localized in lysosomes and the Golgi apparatus of HeLa cells, respectively. ${ }^{17}$ These results suggest that Golgi apparatus (for $\mathrm{ZnPc}$ ) and lysosomes (for TMPyP) are the subcellular targets directly affected by synergistic treatment and therefore responsible for triggering apoptosis. In this regard, several studies have demonstrated that release of cytochrome $c$ can be triggered from lysosomal cathepsins that induce breakage of Bid in t-Bid, capable of inducing relocation of Bax. ${ }^{39,40}$ Previously, we have seen that $\mathrm{ZnPc}$ induces activation of Golgi caspase-2 in A-549 cells, and initiates apoptotic process. ${ }^{22}$

Although one of the goals of this investigation was to get higher efficiency in order to inactivate tumor cells, a secondary rather surprising result was that cells underwent the complete apoptotic process without losing their adhesion to substrate. In relation with this, cell detachment from extracellular matrix is also reported as a potent apoptotic inducer. ${ }^{41}$ It is well known that an absence of cell attachment to the extracellular matrix triggers a cell death mechanism termed anoikis, which is mediated by different signaling pathways. However, tumor cells are characterized by being able to avoid anoikis in response to loss of adhesion. Thus, anoikis resistance is clearly related to the ability of tumor cells to induce metastatic processes as reflected in a recent review. ${ }^{42}$

Many studies have reported that FAK has a key role in neoplastic transformation, metastasis, and cancer progression. ${ }^{43}$ However, data on the role of FAK in cytotoxicity induced by different agents are somewhat contradictory, and both downregulation and upregulation of FAK activity have been described. ${ }^{44}$ Our results show that FAK was located in focal adhesion complexes of HeLa control cells. However, $1 \mathrm{~h}$ 
after synergistic-PDT, FAK signals practically cannot be visualized. Likewise, cells also undergo profound and irreversible reorganization of F-actin, which is accompanied by morphological alterations in cell shape. An extended time course up to $24 \mathrm{~h}$ showed that both FAK and F-actin did not return to control conditions in any cell. This fact provides strong support for the hypothesis that combined phototreatment is able to cleave or degrade FAK protein. Likewise, scratch wound assays also corroborate that HeLa cells' migration was completely inhibited at $48 \mathrm{~h}$ after photodynamic treatment. A decrease in FAK phosphorylation has been detected in nasopharyngeal carcinoma cells treated with 5-aminolevulinic acid (ALA)-PDT. ${ }^{45}$ Several data indicate that ROS generation after a given treatment is able to produce cleavage of FAK or downregulation of FAK activity. ${ }^{46,47}$ Considering that ROS levels are an important factor to avoid anoikis in tumor cells ${ }^{42}$ and that PDT produces ROS (mainly ${ }^{1} \mathrm{O}_{2}$ ), it is clear that the photodynamic treatment described here has notable advantages. Our results indicate that $\mathrm{TMPyP}+\mathrm{ZnPc}+2.4 \mathrm{~J} / \mathrm{cm}^{2}$ is very effective in killing tumor cells, without avoiding apoptosis, as was observed in resistant tumor cells. It is noteworthy that only an increased expression of FAK has been described in squamous carcinoma cells resistant to PDT with Me-ALA. ${ }^{48}$ In the same research, more stress fibers were detected after PDT. Obviously, further investigations are required to identify which adhesion molecules and signaling pathways are capable of inducing massive apoptotic response without losing the adhesion of cells to substrate.

Finally, our results in vivo demonstrated an effective accumulation of $\mathrm{ZnPc}$ and TMPyP in tumor-bearing mice, $24 \mathrm{~h}$ after i.v. injection of the PSs. This is a fundamental property of PSs to assess their possible clinical application. Although far from complete, the results presented here show the in vivo effectiveness of PDT with combined PSs against solid tumors. However, a more precise interpretation of the present findings will hopefully be provided by studies on the mechanism by which simultaneous administration of both PSs induces a significant retardation of tumor growth. In vivo biodistribution studies as well as histological and ultrastructural analysis are in progress in our laboratory.

Summarizing our data, the major findings of this study revealed the efficacy of combined administration of two PSs (ZnPc and TMPyP) to induce synergistic tumor cell photoinactivation with minimal PDT doses by apoptosis and inhibition of cell migration. It appears that combinations of effective PSs that act by different mechanisms could be used to increase the minimally invasive PDT response and, therefore, should be considered the future of PDT.

\section{Materials and Methods}

Cell cultures. Human cervix adenocarcinoma (HeLa), human breast adenocarcinoma (MCF-7) and human keratinocyte (HaCaT) cells were grown as monolayer cultures in Dulbecco's modified Eagle's medium (DMEM; SigmaAldrich, St Louis, MA, USA) supplemented with 10\% (v/v) fetal bovine serum (FBS), $50 \mathrm{U} / \mathrm{ml}$ penicillin and $50 \mu \mathrm{g} / \mathrm{ml}$ streptomycin (whole medium). All products were purchased from Gibco (Paisley, UK) and sterilized by means of $0.22 \mu \mathrm{m}$ filters (Millipore, Billerica, MA, USA). Cell cultures were performed in a $5 \% \mathrm{CO}_{2}$ atmosphere plus $95 \%$ air at $37^{\circ} \mathrm{C}$, and maintained in a SteriCult 200 (HucoaErloss, Madrid, Spain) incubator. Depending on the experiment, cells were seeded in $25 \mathrm{~cm}^{2}$ flasks (F25), in 24-well plates with or without $10 \mathrm{~mm}$ square coverslips, or in $35 \mathrm{~mm}$ Petri dishes with $22 \mathrm{~mm}$ square coverslips. Subconfluent cell cultures were used. All sterile plastics were from Corning (New York, NY, USA).

\section{Photosensitizers}

$Z n P c$ preparation and treatment conditions: Hydrophobic zinc(II)-phthalocyanine (ZnPc) was acquired from Sigma-Aldrich. A $0.5 \mathrm{mg} / \mathrm{ml}$ stock solution was prepared in pyridine (Panreac Quimica, Barcelona, Spain) and stored at $4{ }^{\circ} \mathrm{C}$ until use. $\mathrm{ZnPc}$ was incorporated into dipalmitoyl-phosphatidylcholine (DPPC) liposomes (Sigma-Aldrich) according to the injection procedure described previously by Villanueva et $a l^{30}$ Liposome solutions were sterilized by filtration with a $0.22-\mu \mathrm{m}$-diameter filter (Millipore), and used during 2 weeks to ensure the stability of liposomes. Concentration of ZnPc-DPPC stock solution was measured using a Shimadzu UV-1601 spectrophotometer (Shimadzu Scientific Instruments, Kyoto, Japan); for in vitro studies, ZnPc stock solution was diluted in phosphate buffered saline (PBS) (Invitrogen, Paisley, UK) to the desired concentration $\left(5 \times 10^{-8} \mathrm{M}\right)$.

TMPyP supply and treatment conditions: Hydrophilic TMPyP from Sigma-Aldrich was diluted in PBS to a concentration of $10^{-6} \mathrm{M}$, which was spectrophotometrically measured taking into account the molar extinction coefficient $\left(\varepsilon_{424 \mathrm{~nm}}=194.000 \mathrm{M}^{-1} \mathrm{~cm}^{-1}\right)$.

Preparation of PS mixture: Combined solutions contained $5 \times 10^{-8} \mathrm{M} \mathrm{ZnPc}$ and $10^{-6} \mathrm{M}$ TMPyP diluted in PBS.

Photodynamic treatments. Cells seeded in 24-well plates (with or without coverslip) or F25 flasks, depending on subsequent processing, received photodynamic treatments with either a single PS (ZnPc or TMPyP) or both PSs simultaneously (ZnPc + TMPyP). Accordingly, cells were incubated for $1 \mathrm{~h}$ with $5 \times 10^{-8} \mathrm{M} Z \mathrm{ZnPc}$-DPPC solution, $10^{-6} \mathrm{M}$ TMPyP or $5 \times 10^{-8} \mathrm{M} \mathrm{ZnPc}+10^{-6}$ $M$ TMPyP in PBS, washed three times with PBS and maintained in whole medium during irradiation and post-treatment time $(1,3,6,18,24$, or $48 \mathrm{~h})$. Irradiations were performed by means of a red light-emitting diode (LED) device $(\lambda=650 \pm 20$ $\mathrm{nm}$ ) with a fluence rate of $4 \mathrm{~mW} / \mathrm{cm}^{2}$, measured with an M8 Spectrum Power Energy meter (Merchantek Inc., San Diego, CA, USA). Cells were irradiated for 10 or $15 \mathrm{~min}$, corresponding to total light doses of 2.4 or $3.6 \mathrm{~J} / \mathrm{cm}^{2}$, respectively (total light dose $\left(\mathrm{J} / \mathrm{cm}^{2}\right)=$ fluence rate $\left(\mathrm{W} / \mathrm{cm}^{2}\right) \times$ treatment time $\left.(\mathrm{s})\right)$. Either immediately or at different times after irradiation different methodological protocols were performed. Besides, experiments were carried out by incubation with the corresponding PSs but without irradiation (dark toxicity), in order to examine possible cytotoxic effect exercised by PSs, either alone or combined. It is important to note that the conditions described above were chosen after having done several previous studies, using different concentrations of PSs and different irradiation times.

\section{Cell viability studies}

MTT assay. Dark- and photo-toxicity was assessed by MTT colorimetric assay 24 and $48 \mathrm{~h}$ after treatments. Immediately prior to use, a stock solution of dimethylthiazolyl-diphenyl-tetrazolium bromide (MTT; Sigma-Aldrich, $1 \mathrm{mg} / \mathrm{ml}$ ) in PBS was prepared. Five hundred microliters of this MTT solution $(50 \mu \mathrm{g} / \mathrm{ml}$ MTT in culture medium) was added to each culture dish without coverslip. Cells were incubated for $3 \mathrm{~h}$, then reduced formazan was extracted with $500 \mu \mathrm{l}$ dimethylsulfoxide and absorbance measured at $570 \mathrm{~nm}$ in a SpectraFluor spectrophotometer (Tecan Group Ltd, Männedorf, Switzerland). Cell survival was expressed as the percentage of absorption of treated cells in comparison with that of control cells. Data corresponded to mean values \pm standard deviation from at least five different experiments. For statistical calculations one-way ANOVA Tukey's test and the software GraphPad Prism (GraphPad Software, La Jolla, CA, USA) were used. $P$ values $\left.<0.05\left(^{*}\right),<0.01{ }^{* *}\right)$, and $<0.0001{ }^{\left({ }^{* * *}\right)}$ were considered as statistically significant.

\section{Morphological studies}

NR and Hoechst-33258 (H-33258) staining: Morphological changes after different photodynamic treatments were assessed by visualizing control and treated cells under light and fluorescence microscopy. Cells were fixed with methanol at $-20{ }^{\circ} \mathrm{C}$ for $5 \mathrm{~min}$, stained with NR (Panreac Quimica; $0.5 \%$ in distilled water, $2 \mathrm{~min}$ ) for general morphology, or with H-33258 (Sigma-Aldrich; $5 \mu \mathrm{g} / \mathrm{ml}$ in distilled water, $3 \mathrm{~min}$ ) for visualization of DNA. After washing and air drying, preparations were mounted in DePeX (Serva, Heidelberg, Germany). In 
some cases, cells were observed under light microscopy (phase contrast or differential interference contrast, DIC) using an inverted microscope, without being processed, to avoid possible morphological artifacts.

Scanning electron microscopy. HeLa cells were fixed in $3 \%$ glutaraldehydePBS (Taab Laboratories, Berkshire, UK) for $1 \mathrm{~h}$, washed 3 times in PBS, and immediately postfixed in $1 \%$ osmium tetroxide-PBS (Taab Laboratories) for another hour. After dehydration in graded ethanol series, samples were critical point dried and sputter-coated with 10\% gold using Emitech (Ashford, Kent, UK) K850 and SC502 instruments. Observations were performed in a Phillips (Eindhoven, The Netherlands) XL30 scanning electron microscope at an accelerating voltage of $20 \mathrm{kV}$.

Transmission electron microscopy: At predetermined times after PDT treatments, HeLa cells were fixed in $2 \%$ glutaraldehyde $+1 \%$ tannic acid in $0.4 \mathrm{M}$ HEPES buffer at $\mathrm{pH} 7.2$ for $2 \mathrm{~h}$ at room temperature (RT), postfixed in a mixture of $1 \%$ osmium tetroxide and $0.8 \%$ potassium ferricyanide in PBS (Taab Laboratories) for $1 \mathrm{~h}$, dehydrated and embedded in Epon. Ultrathin sections were doubly stained with uranyl acetate and lead citrate as usual. Observations and photography were performed in a JEOL (Tokyo, Japan) JEM-1011 transmission electron microscope using a Gatan (Pleasanton, CA, USA) Erlangshen ES 1000W camera.

\section{Characterization of cell death mechanisms}

Flow cytometry analysis: Probe 3,3'-dihexyloxacarbocyanine iodide ( $\mathrm{DiOC}_{6}(3)$; Sigma-Aldrich) was used for detection of $\Delta \psi_{\mathrm{m}}$ by flow cytometry 1 and $18 \mathrm{~h}$ after synergistic photodynamic treatment. Hela cells were trypsinized (harvesting also detached cells), centrifuged for $5 \mathrm{~min}$ at 1500 r.p.m. (rotor radius: $7 \mathrm{~cm})$ and incubated for $30 \mathrm{~min}$ with $40 \mathrm{nM} \mathrm{DiOC}(3)$ at $37^{\circ} \mathrm{C}$.

Furthermore, the ApoScreen Annexin-V Apoptosis Kit was used in order to detect one of the earliest events in apoptosis, externalization of phosphatidylserine (PPS) in living cells. Soon after apoptosis is induced, PPS is translocated from the inner leaflet of the plasma membrane to the outer leaflet. This assay uses fluoresceinlabeled annexin-V (annexin-fluorescein isothiocyanate (FITC)), which has a strong and specific affinity for PPS, to monitor PPS translocation that occurs because of apoptosis. Use of annexin-V-FITC in combination with PI allows discrimination between early (annexin ${ }^{+}, \mathrm{Pl}^{-}$) and late apoptotic cells (annexin ${ }^{+}, \mathrm{Pl}^{+}$).

For this purpose, HeLa cells 1 and $3 \mathrm{~h}$ after synergistic treatment were trypsinized, centrifuged for $5 \mathrm{~min}$ at 1500 r.p.m., washed twice in cold PBS and resuspended in cold $1 \times$ binding buffer to a concentration of $1 \times 10^{6} \mathrm{cell} / \mathrm{s} / \mathrm{ml}$. Then, $10 \mu \mathrm{l}$ of annexin-FITC was added to $100 \mu \mathrm{l}$ of cell suspension; each tube was gently vortexed and incubated for $15 \mathrm{~min}$ on ice, protected from light. Without washing, 380 $\mu \mathrm{l}$ of cold $1 \times$ binding buffer $+10 \mu \mathrm{l}$ of PI $(50 \mu \mathrm{g} / \mathrm{ml})$ was added to each tube and samples were analyzed immediately.

Measurements were performed using a Coulter Epics XL-MCL flow cytometer (Beckman-Coulter Inc., Fullerton, CA, USA) with an argon laser line at $488 \mathrm{~nm}$ and complemented with appropriate filters.

TUNEL assay. Apoptotic cell death induced 3 and $6 \mathrm{~h}$ after PDT was confirmed by TUNEL (terminal deoxynucleotidyl transferase-mediated dUTP nick end labeling) assay according to the manufacturer's instructions (Roche, Penzberg, Germany). HeLa cells seeded on coverslips were fixed for $20 \mathrm{~min}$ in formol-PBS (1:10) at $4{ }^{\circ} \mathrm{C}$, permeabilized for 2 min with $0.1 \%$ Triton X-100 (Sigma-Aldrich) and incubated for $1 \mathrm{~h}$ with TUNEL reaction mixture at $37^{\circ} \mathrm{C}$. After washing with PBS, preparations were mounted with ProLong Gold antifade reagent (Molecular Probes, Eugene, OR, USA).

Western blot analysis: For protein analysis by western blot techniques, samples from HeLa controls, ZnPc-PDT, TMPyP-PDT, and ZnPc + TMPyP-PDTtreated cell cultures were processed $6 \mathrm{~h}$ after the corresponding treatment. Whole protein content was extracted by lysis using RIPA buffer $(50 \mathrm{ml}$ of distilled water with $50 \mathrm{mM}$ Tris- $\mathrm{HCl}$ at $\mathrm{pH} 8 ; 150 \mathrm{mM} \mathrm{NaCl} ; 1 \%$ (v/v) Igepal CA630 (all from Sigma-Aldrich) and $0.1 \%$ (v/v) SDS; complemented with a tablet of complete EDTA-free protease inhibitors (Roche)). Protein concentration was determined using a BCA assay kit (Pierce, Rockford, IL, USA), and samples were loaded and separated on $15 \%$ SDS-PAGE and transferred to a nitrocellulose membrane using a Mini-Protean 3 equipment, according to the manufacturer's instructions (Bio-Rad, Hercules, CA, USA). Chemoluminescent detection of proteins was performed with a mouse monoclonal anti- $\beta$-actin (clone AC-15; Sigma-Aldrich) antibody, and a mouse monoclonal anti-PARP (clone C-2-10; Sigma-Aldrich) antibody, using overnight incubation at $4{ }^{\circ} \mathrm{C}$. Secondary antibody was sheep antimouse IgG conjugated to horseradish peroxidase (Amersham Biosciences, Buckinghamshire, UK). Bands were developed on a Curix CP-G Plus paper (AGFA, Barcelona, Spain) with Western Blotting Luminol Reagent (Roche).

Bax and cytochrome c indirect immunofluorescence assay. For indirect immunofluorescence detection of pro-apoptotic Bax protein or cytochrome c, HeLa cells on coverslips were fixed in formol-PBS $(1: 10)$ for 20 min at $4{ }^{\circ} \mathrm{C}$, washed three times with PBS (5 min each), and permeabilized with $0.5 \%$ Triton X-100. After 5 min, Triton X-100 was removed and cells were incubated in blocking solution ( $5 \%$ bovine serum albumin, $5 \%$ FBS, $0.02 \%$ Triton X-100 in PBS) for $30 \mathrm{~min}$ at RT. Once removed from blocking solution, $25 \mu \mathrm{l}$ of a 1:100 solution of primary antibody (monoclonal mouse anti-Bax (sc-20067); Santa Cruz Biotechnology, Santa Cruz, CA, USA) or $25 \mu$ l of a 1:25 solution of primary antibody (monoclonal mouse anti-cytochrome $c$, Invitrogen) was added to each sample and incubated at $37^{\circ} \mathrm{C}$ for $1 \mathrm{~h}$. Three 5 -min washings with PBS were then carried out before addition of Triton X-100 for 5 min. Incubation of secondary antibody (Fab specific goat anti-mouse FITC-IgG; Sigma-Aldrich) was identical to that of the first one and so were final washings. Cells were counterstained using $\mathrm{H}-33258$ and mounted with ProLong Gold antifade reagent.

Indirect immunofluorescence for FAK and staining for F-actin. A combined analysis of actin microfilaments and FAK was performed for assessing alterations produced after PDT treatments. FAK and actin microfilaments were visualized by indirect immunofluorescence (FAK) and labeling with tetramethylrhodamine isothiocyanate (TRITC)-conjugated phalloidin (actin). HeLa cells grown on coverslips were fixed in formol-PBS (1:10) for $20 \mathrm{~min}$ at $4{ }^{\circ} \mathrm{C}$, washed three times with PBS (5 min each) and blocked as described above. Once removed from blocking solution, $25 \mu \mathrm{l}$ of a 1:50 solution of primary antibody (monoclonal purified mouse anti-human FAK (pY397), BD Biosciences, San Jose, CA, USA) was added to each sample and incubated at $37^{\circ} \mathrm{C}$ for $1 \mathrm{~h}$. Three 5 -min washings with PBS were then carried out before addition of Triton X-100 for $5 \mathrm{~min}$. Incubation of secondary antibody (Fab specific goat anti-mouse FITC-IgG; Sigma-Aldrich) was identical to that applied for Bax. F-actin was visualized in the same samples by incubation with phalloidin-TRITC (Sigma-Aldrich) solution (1:200) at $37^{\circ} \mathrm{C}$ in a wet chamber for $30 \mathrm{~min}$. Finally, cells were washed three times with PBS, counterstained with $\mathrm{H}-33258$ and mounted with Prolong Gold antifade reagent as described above.

Cell migration by scratch wound assay. To determine if quantifiable cell migration occurred after synergistic-PDT treatment, in vitro scratch assays were performed. HeLa cells were seeded in 24-well plates and when cells reached a confluence of $95 \%$ wounds were made in cell culture using a tip. Culture medium was changed to remove loose cell debris, and a defined area of the wound was photographed under an inverted microscope for a total period of $48 \mathrm{~h}$.

In vivo localization studies. Female C57BL/6 mice (18-20 g body weight) obtained from Charles River were used as experimental models, kindly provided by Dr. Barber (CNB, Madrid, Spain). Amelanotic melanoma cells (B78H1), kindly provided by Dr. Jori (Padova, Italy), were transplanted into the upper flank of mice by subcutaneous injection of $100 \mu \mathrm{l}\left(10^{6}\right.$ cells) of a sterile cell suspension in PBS. Cells were cultured as described above. At 15-20 days after injection of $\mathrm{B} 78 \mathrm{H} 1$ cells, when tumor external diameter was in the $0.6-0.8 \mathrm{~cm}$ range, PSs were administered and PBS alone was applied as control. ZnPc and TMPyP, at a dose of $0.5 \mathrm{mg} / \mathrm{kg}$ and $4.1 \mathrm{mg} / \mathrm{kg}$ body weight, respectively, were administered by i.v. injection into the tail vein. For each experiment, six groups of mice (three mice per each time point) were used, namely control PBS i.v., ZnPc i.v., and TMPyP i.v. Localization of each PS was studied $24 \mathrm{~h}$ after i.v. injection by using a macroscopic fluorescence imaging system Aequoria MDS equipped with an Argus Photon Counting camera (Hamamatsu Photonics K.K., Iwata, Japan) and the proper exciting filters $(655 \mathrm{~nm}$ for $\mathrm{ZnPc}$, and $475 \mathrm{~nm}$ for TMPyP). Image processing and analysis (IPA) were performed using public domain ImageJ 1.46 software (http://rsb.info.nih.gov/ij).

Antitumor effects of PDT treatments. At 10-15 days after subcutaneous injection of $\mathrm{B} 78 \mathrm{H} 1$ cells, when tumor external diameter was in the 
$0.6-0.8 \mathrm{~cm}$ range, individual $(\mathrm{ZnPc}, \mathrm{TMPyP})$ or combined $(\mathrm{ZnPc}+\mathrm{TMPyP}) \mathrm{PSs}$ were injected into mouse caudal vein at a dose of $0.5 \mathrm{mg} / \mathrm{kg}(\mathrm{ZnPc})$ and $/ \mathrm{or} 4.1 \mathrm{mg} /$ $\mathrm{kg}$ (TMPyP) body weight. Irradiation of amelanotic melanoma in anesthetized tumor-bearing mice was performed for a time interval of $24 \mathrm{~h}$ after i.v. injection of one or two PSs by using the 600-700 nm wavelength range, which was isolated by a set of bandpass filters from the emission of a quartz-halogen lamp (Teclas, Lugano, Switzerland). Light source was operated at a fluence rate of $175 \mathrm{~mW} / \mathrm{cm}^{2}$, and the total delivered light dose was $300 \mathrm{~J} / \mathrm{cm}^{2}$. An interval of $24 \mathrm{~h}$ between PS administration and light exposure was chosen based on in vivo localization studies. For experiments, tumor-bearing mice were randomly divided into the following groups (at least six mice per experimental group): (i) absolute control (no light and no drug), (ii) dark control (injection of each PS alone or in combination but no red light), (iii) light control (no drug; mice irradiated with red light in the absence of any PS), (iv) mice irradiated $24 \mathrm{~h}$ after i.v. injection of one PS, and (v) mice irradiated $24 \mathrm{~h}$ after i.v. injection of two PSs, under the same experimental conditions. The effectiveness of the treatment was evaluated by comparing the rate of tumor growth as a function of the post-irradiation time for photosensitised mice with that observed for control mice that had not been exposed to light and had not been injected with any PS. Tumor size was measured at daily intervals by means of a caliper. Individual tumor volumes $(V)$ were calculated assuming a hemiellipsoidal structure for tumor nodule and measuring the two perpendicular axes $(a$ and $b$ ) and height $(c)$. Application of the relationship $V=2 / 3 \pi(a / 2 \times b / 2 \times c)$ yielded tumor volume. Mice were followed daily to determine the day on which the tumor diameters equaled or exceeded $1 \mathrm{~cm}$ tumor volume. At this time, mice were killed by euthanasia in line with the rules established by the University of Padova ethical committee for treatment of experimental animals. In no case was spontaneous regression or remission of the tumor observed.

Optical microscopy. Observations of samples processed for optical microscopy (bright field and fluorescence) were made with an Olympus BX61 epifluorescence microscope equipped with an Olympus DP50 digital camera (Olympus, Center Valley, PA, USA), and processed using the Photoshop CS5 software (Adobe Systems). The following filters were used in order to visualize the fluorescence signal of probes and PSs: UV (365-390 nm) for $\mathrm{H}-33258$ and $\mathrm{ZnPc}$, blue $(460-490 \mathrm{~nm})$ for TUNEL, FITC, and TMPyP, and green $(510-550 \mathrm{~nm})$ for TRITC. In addition, living cells were imaged under a differential interference contrast (DIC) inverted microscope (Leica DMI6000B) equipped with a Leica DFC420 C digital camera (Leica Microsystems, Heerbrugg, Switzerland) and images were processed with the same software. Moreover, analysis of cytoskeleton, adhesion protein FAK, Bax and cytochrome $c$ was performed using a multispectral Leica TCS SP5 confocal microscope, operating with $405 \mathrm{~nm}$ (argon-UV), $488 \mathrm{~nm}$ (argon), and $561 \mathrm{~nm}$ (DPSS) laser lines.

\section{Conflict of Interest}

The authors declare no conflict of interest.

Acknowledgements. We recognize the valuable contribution of Prof. Giulio Jori (Department of Biology, University of Padova, Italy), Sylvia Gutiérrez (Confocal Microscopy, Centro Nacional de Biotecnología, Madrid), Carmen Moreno-Ortiz (Flow Cytometry, Centro Nacional de Biotecnología, Madrid), Cristina Patiño (TEM, Centro Nacional de Biotecnología, Madrid), Esperanza Salvador (SEM, Servicio Interdepartamental de Investigación, Universidad Autónoma de Madrid), and Julio Gutiérrez (Department of Immunology and Oncology, Centro Nacional de Biotecnología, Madrid). This work was supported by the Spanish Ministry of Economy and Competitiveness (CTQ2010-20870-C03-03)

1. Agostinis P, Berg K, Cengel KA, Foster TH, Girotti AW, Gollnick SO et al. Photodynamic therapy of cancer: an update. CA Cancer J Clin 2011; 61: 250-281.

2. Yoo JO, Ha KS. New insights into the mechanisms for photodynamic therapy-induced cancer cell death. Int Rev Cell Mol Biol 2012; 295: 139-174.

3. Allison RR, Moghissi K. Oncologic photodynamic therapy: clinical strategies that modulate mechanisms of action. Photodiagnosis. Photodyn Ther 2013; 10: 331-341.

4. Rizvi I, Celli JP, Evans CL, Abu-Yousif AO, Muzikansky A, Pogue BW et al. Synergistic enhancement of carboplatin efficacy with photodynamic therapy in a threedimensional model for micrometastatic ovarian cancer. Cancer Res 2010; 70: 9319-9328.
5. Wei XQ, Ma HQ, Liu AH, Zhang YZ. Synergistic anticancer activity of 5-aminolevulinic acid photodynamic therapy in combination with low-dose cisplatin on Hela cells. Asian Pac J Cancer Prev 2013; 14: 3023-3028.

6. Nakano A, Watanabe D, Akita Y, Kawamura T, Tamada Y, Matsumoto Y. Treatment efficiency of combining photodynamic therapy and ionizing radiation for Bowen's disease. J Eur Acad Dermatol Venereol 2011; 25: 475-478.

7. Torres T, Fernandes I, Costa V, Selores M. Photodynamic therapy as adjunctive therapy for morpheaform basal cell carcinoma.. Acta Dermatovenerol Alp Panonica Adriat 2011; 20: 23-25.

8. Bai D, Xia X, Yow CMN, Chu ESM, Xu C. Hypocrellin B-encapsulated nanoparticlemediated rev-caspase-3 gene transfection and photodynamic therapy on tumor cells. Eur J Pharmacol 2011; 650: 496-500.

9. Kwitniewski M, Juzeniene A, Glosnicka R, Moan J. Immunotherapy: a way to improve the therapeutic outcome of photodynamic therapy? Photochem Photobiol Sci 2008; 7 : 1011-1017

10. Castano AP, Mroz P, Wu MX, Hamblin MR. Photodynamic therapy plus low-dose cyclophosphamide generates antitumor immunity in a mouse model. Proc Natl Acad SCi USA 2008; 105: 5495-5500

11. Separovic D, Bielawski J, Pierce JS, Merchant S, Tarca AL, Bhatti G et al. Enhanced tumor cures after Foscan photodynamic therapy combined with the ceramide analog LCL29. Evidence from mouse squamous cell carcinomas for sphingolipids as biomarkers of treatment response. Int J Oncol 2011; 38: 521-527.

12. Ferrario A, Lim S, Xu F, Luna M, Gaffney KJ, Petasis NA et al. Enhancement of photodynamic therapy by 2,5-dimethyl celecoxib, a non-cyclooxygenase-2 inhibitor analog of celecoxib. Cancer Lett 2011; 304: 33-40.

13. Paszko E, Ehrhardt C, Senge MO, Kelleher DP, Reynolds JV. Nanodrug applications in photodynamic therapy. Photodiagnosis Photodyn Ther 2011; 8: 14-29.

14. Master A, Livingston M, Gupta AS. Photodynamic nanomedicine in the treatment of solid tumors: perspectives and challenges. J Control Release 2013; 168: 88-102.

15. Barras A, Boussekey L, Courtade E, Boukherroub R. Hypericin-loaded lipid nanocapsules for photodynamic cancer therapy in vitro. Nanoscale 2013; 5: 10562-10572.

16. Schneider-Yin X, Kurmanaviciene A, Roth M, Roos M, Fedier A, Minder E et al. Hypericin and 5-aminolevulinic acid-induced protoporphyrin IX induce enhanced phototoxicity in human endometrial cancer cells with non-coherent white light. Photodiagnosis Photodyn Ther 2009; 6: 12-18.

17. Villanueva A, Stockert JC, Cañete M, Acedo P. A new protocol in photodynamic therapy: enhanced tumour cell death by combining two different photosensitizers. Photochem Photobiol Sci 2010; 9: 295-297.

18. Besic Gyenge $\mathrm{E}$, Lüscher D, Forny $\mathrm{P}$, Antoniol M, Geisberger $\mathrm{G}$, Walt $\mathrm{H}$ et al. Photodynamic mechanisms induced by a combination of hypericin and a chlorin basedphotosensitizer in head and neck squamous cell carcinoma cells. Photochem Photobiol 2013; 89: 150-162

19. Villanueva A, Vidania R, Stockert JC, Cañete M, Juarranz A. Photodynamic effects on cultured tumor cells. Cytoskeleton alterations and cell death mechanisms. In: Nalwa HS (eds) Handbook of Photochemistry and Photobiology Los AngelesAmerican Scientific Publishers, 2003. pp 1-39.

20. Wu L, Yang L, Huang J, Zhang L, Weng X, Zhang X et al. Cationic ester porphyrins cause high levels of phototoxicity in tumor cells and induction of apoptosis in HeLa cells. Chem Biodivers 2009; 6: 1066-1076.

21. Abdelghany SM, Schmid D, Deacon J, Jaworski J, Fay F, McLaughlin KM et al. Enhanced antitumor activity of the photosensitizer meso-Tetra(N-methyl-4-pyridyl) porphine tetra tosylate through encapsulation in antibody-targeted chitosan/alginate nanoparticles. Biomacromolecules 2013; 14: 302-310.

22. Cristobal J, Stockert JC, Villanueva A, Rello-Varona S, Juarranz A, Cañete M. Caspase-2: a possible trigger of apoptosis induced in $\mathrm{A}-549$ tumor cells by $\mathrm{ZnPc}$ photodynamic treatment. Int J Oncol 2006; 28: 1057-1063

23. Rello-Varona S, Stockert JC, Cañete M, Acedo P, Villanueva A. Mitotic catastrophe induced in HeLa cells by photodynamic treatment with Zn(II)-phthalocyanine. Int J Oncol 2008; 32: 1189-1196.

24. Lau JTF, Lo PC, Fong WP, Ng DKP. A Zinc(II) phthalocyanine conjugated with an oxaliplatin derivative for dual chemo- and photodynamic therapy. J Med Chem 2012; 55 : 5446-5454.

25. Valeriote $\mathrm{F}$, Lin $\mathrm{H}$. Synergistic interaction of anticancer agents: a cellular perspective. Cancer Chemother Rep 1975; 59: 895-900.

26. Rello S, Stockert JC, Moreno V, Gamez A, Pacheco M, Juarranz A et al. Morphological criteria to distinguish cell death induced by apoptotic and necrotic treatments. Apoptosis 2005; 10: 201-208

27. Ke MS, Xue L, Feyes DK, Azizuddin K, Baron ED, McCormick TS et al. Apoptosis mechanisms related to the increased sensitivity of Jurkat T-cells vs A431 epidermoid cells to photodynamic therapy with the phthalocyanine Pc 4. Photochem Photobiol 2008; 84: 407-414.

28. Berlanda J, Kiesslich T, Engelhardt V, Krammer B, Plaetzer K. Comparative in vitro study on the characteristics of different photosensitizers employed in PDT. J Photochem Photobiol B 2010; 100: 173-180.

29. Sasnouski S, Pic E, Dumas D, Zorin V, D'Hallewin M, Guillemin F et al. Influence of incubation time and sensitizer localization on meta-tetra (hydroxyphenyl) 
chlorin (mTHPC)-induced photoinactivation of cells. Radiat Res 2007; 168: 209-217.

30. Villanueva A, Domínguez V, Polo S, Vendrell V, Sanz C, Cañete T et al. Photokilling mechanisms induced by zinc(II)-phthalocyanine on cultured tumor cells. Oncol Res 1999; 11: 447-453.

31. Galluzzi L, Aaronson SA, Abrams J, Alnemri ES, Andrews DW, Baehrecke EH et al. Guidelines for the use and interpretation of assays for monitoring cell death in higher eukaryotes. Cell Death Differ 2009; 16: 1093-1107.

32. Galluzzi L, Vitale I, Abrams JM, Alnemri ES, Baehrecke EH, Blagosklonny MV et al. Molecular definitions of cell death subroutines: recommendations of the Nomenclature Committee on Cell Death 2012. Cell Death Differ 2012; 19: 107-120.

33. Mroz P, Yaroslavsky A, Kharkwal GB, Hamblin MR. Cell Death Pathways in Photodynamic Therapy of Cancer. Cancers 2011; 3: 2516-2539.

34. Ruiz-Gonzalez R, Acedo P, Sanchez-Garcia D, Nonell S, Cañete M, Stockert JC et al. Efficient induction of apoptosis in HeLa cells by a novel cationic porphycene photosensitizer. Eur J Med Chem 2013; 63: 401-414.

35. Nicotera P, Melino G. Regulation of the apoptosis-necrosis switch. Oncogene 2004; 23: 2757-2765.

36. Castano AP, Demidova TN, Hamblin MR. Mechanisms in photodynamic therapy: part two-cellular signaling, cell metabolism and modes of cell death. Photodiagnosis Photodyn Ther 2005; 2: 1-23.

37. Zamzami N, Kroemer G. Methods to measure membrane potential and permeability transition in the mitochondria during apoptosis. Methods Mol Biol 2004; 282: 103-115.

38. Plaetzer K, Krammer B, Berlanda J, Berr F, Kiesslich T. Photophysics and photochemistry of photodynamic therapy: fundamental aspects. Lasers Med Sci 2009; 24: 259-268.

39. Česen MH, Pegan K, Spes A, Turk B. Lysosomal pathways to cell death and their therapeutic applications. Exp Cell Res 2012; 318: 1245-1251.
40. Repnik U, Stoka V, Turk V, Turk B. Lysosomes and lysosomal cathepsins in cell death Biochim Biophys Acta 2012; 1824: 22-33.

41. Taylor RC, Cullen SP, Martin SJ. Apoptosis: controlled demolition at the cellular level. Nat Rev Mol Cell Biol 2008; 9: 231-241.

42. Paoli $P$, Giannoni $E$, Chiarugi $P$. Anoikis molecular pathways and its role in cancer progression. Biochim Biophys Acta 2013; 1833: 3481-3498.

43. Golubovskaya VM. Focal adhesion kinase as a cancer therapy target. Anticancer Agents Med Chem 2010; 10: 735-741.

44. Zheng Y, Lu Z. Paradoxical roles of FAK in tumor cell migration and metastasis. Cell Cycle 2009; 8: 3474-3479.

45. Yang TH, Chen CT, Wang CP, Lou PJ. Photodynamic therapy suppresses the migration and invasion of head and neck cancer cells in vitro. Oral Oncol 2007; 43: 358-365.

46. Mian MF, Kang C, Lee S, Choi JH, Bae SS, Kim SH et al. Cleavage of focal adhesion kinase is an early marker and modulator of oxidative stress-induced apoptosis. Chem Biol Interact 2008; 171: 57-66.

47. Chatzizacharias NA, Kouraklis GP, Theocharis SE. Disruption of FAK signaling: a side mechanism in cytotoxicity. Toxicology 2008; 245: 1-10.

48. Milla LN, Cogno IS, Rodriguez ME, Sanz-Rodriguez F, Zamarron A, Gilaberte $Y$ et al. Isolation and characterization of squamous carcinoma cells resistant to photodynamic therapy. J Cell Biochem 2011; 112: 2266-2278.

(c) $(-)$ Cell Death and Disease is an open-access journal published by Nature Publishing Group. This work is licensed under a Creative Commons Attribution-NonCommercialNoDerivs 3.0 Unported License. To view a copy of this license, visit http://creativecommons.org/licenses/by-nc-nd/3.0/

\section{Supplementary Information accompanies this paper on Cell Death and Disease website (http://www.nature.com/cddis)}

